\title{
Corporate Governance and Performance of Firms Listed on the Nairobi Securities Exchange
}

\author{
Edward Kobuthi (PhD Candidate), Peter K'Obonyo (PhD), Martin Ogutu ( PhD) \\ PhD Candidate, School of Business, University of Nairobi. \\ Professor, Department of Business Administration, School of Business, University of Nairobi. \\ Associate Professor, Department of Business Administration, School of Business, University of Nairobi.
}

\begin{abstract}
The purpose of this study was to establish the effect of corporate governance on performance of firms listed on the Nairobi Securities Exchange (NSE). The author developed a corporate governance index as a proxy for corporate governance based on the seven attributes of the recently revised Capital Markets Authority (CMA) draft code of corporate governance practices for public listed companies in Kenya. The guidelines cover board operations and control, rights of shareholders, stakeholder relations, ethics and social responsibilities, accountability, risk management and internal audit, transparency and disclosure and supervision and enforcement. The survey questionnaire was the main tool of data collection and was distributed to 56 CEOs and corporation secretaries. The response rate was 87.5\%. Annual reports for 2015 were used to compute the CGI score for the different organizations. The study found a statistically significant relationship between corporate governance and non-financial performance of firms listed on the Nairobi Securities Exchange confirming that organizations can enhance their performance by implementing good corporate governance, specifically those attributes of good corporate governance that matter.
\end{abstract}

Key words: Corporate Governance, CGI_Score, Firm Performance

\section{Introduction}

The last decade has witnessed unprecedented increase in both policy and academic research in corporate governance due to corporate scandals that have triggered some of the largest insolvencies in history (Claessens, 2006). Corporate governance however, traces its origins to 1774 from Adam Smith's publication, "The Wealth of Nations", but gained impetus with the seminal publication by Bearle and Means (1932), "The Modern Corporation and Private Property", work that delineated the separation of ownership and control in the modern corporation and the problems associated with it. Concerns of separation were aggregated by Jensen and Meckling (1976) into the "agency problem" in governing the organization. Well governed organizations tend to perform better than poorly governed ones.

Irungu (2016) observed that Kenya Airways, Mumias Sugar and Uchumi are insolvent, failures which Okoth (2015) attributes to amongst other reasons to poor corporate governance. According to Cytonn Investments (2016), investor's wealth has been eroded to the tune of 223.5 billion shillings between 5 NSE listed companies. This is happening at a time when demand for Kenyan companies' stocks, has risen consistently raising foreign ownership of shares at the NSE to more than a third of market value (Irungu, 2016). From a global perspective corporate governance becomes an issue of systemic stability providing early warning (OECD, 2004). There has been limited empirical corporate governance studies in Kenya about what needs to be included in a comprehensive corporate governance framework. 


\section{Literature Review}

\section{Theoretical Foundations}

Much of prior research on corporate governance has been carried out based on agency theory (Filatotchev \& Boyd, 2009). Agency theory posits that a net reduction in agency costs arising from internal corporate governance structures should help improve performance (Shabbir \& Padget, 2005). This has been the major reason for the formulation of governance reports and the major motivation for empirical studies linking corporate governance and performance and more recently the construction of composite governance indices (Gompers et al., 2003). The resource dependence theory views the board as a reservoir of resources that creates high performance (Haniffa \& Hudaib, 2006) while the stewardship theory contrary to the agency theory's pessimistic self-serving motives of executives suggests a pro-organizational motive of directors (Davis et.al.,1997). The stakeholder theory challenges agency theory's assumption of primacy of shareholders and recognizes the many players who have an interest in the organization (Freeman (1984).

\section{Corporate Governance}

Corporate governance is concerned with the systems used to balance the rights and obligations of the owners and those of non-owner managers. Cadbury (1999) for example defines corporate governance as the system by which organizations are directed and controlled and mainly concentrates on how key internal governance mechanisms interact to maximize shareholder value. Solomon and Solomon (2004) define corporate governance as a system of checks and balances which ensures that companies discharge their accountabilities to all their stakeholders.

Corporate governance attained significance due to the surge of corporate scandals and failures that involved corporate giants such as Enron and World-Com (Claesens (2006). Following the implication of agency theory, prior literature has attempted to establish empirical relationship between internal corporate governance and performance using an equilibrium characteristics model and a compliance-index model. The equilibrium characteristics model assumes that there is an endogenous relationship between internal governance structures and firm performance such that each firm has its own optimal governance structure chosen freely (Gyakari, 2009). Much of prior research on corporate governance has been carried out based on agency theory (Filatotchev \& Boyd, 2009). Agency theory posits that a net reduction in agency costs arising from internal corporate governance structures should help improve performance (Shabbir and Padget, 2005). This has been the major reason for the formulation of governance reports and the major motivation for empirical studies linking corporate governance and performance and more recently the construction of composite governance indices (Gompers et al, 2003).

Varied literature and theoretical perspectives suggest that good corporate governance leads to better firm performance. It has been argued that weak corporate governance leads not only to poor firm performance but it is also conducive for microeconomic crisis (OECD, 2004). Many empirical studies attempted to address the key problems inherent in the separation of ownership and control and are concerned with linking different aspects of corporate governance with firm performance in order to prevent the principle-agent conflict (Haniffa \& Hudaib, 2006). The central premise of this framework is that managers as agents of shareholders can engage in self-serving behaviours that may be inconsistent with the shareholders' wealth maximization objective. This simple theoretical framework has been expanded to research streams shifting the focus from principal-agent conflicts and associated agency costs to the nature and role of owners, boards of directors, and separation of CEO and board chairs, executive remuneration and financial reporting (Filatotchev \& Boyd, 2009).

Munisi and Randoy (2009) found a positive and significant association between corporate governance and performance in companies in Sub- Saharan Africa using accounting measures but a negative and significant association by market valuation. Barako and Brown and Gorgens (2009) found a positive relationship between board diversity and corporate social reporting in Kenyan banks while Obeten and Ocheni (2014) found that better corporate governance resulted to better performance of selected commercial banks in Nigeria. Gyakari (2009) found that results based on compliance index of 100 South African listed firms suggest a statistically significant association between firms' internal corporate governance quality and their financial performance, but got mixed results based on the equilibrium-variable model. 
While the concept of corporate governance and its effect on performance has received considerable attention and is a stable of discussions in corporate board rooms, academic meetings and policy circles, different scholars have conceptualized corporate governance and assessed the constructs differently resulting to different measurements and firm performance implications. In addition, research findings have been contradictory and mixed. These inconsistent findings highlight the need to identify the nature of this relationship more so in the Kenyan context. The extant literature on corporate governance is mostly based on studies carried out in the developed and emerging countries presenting a contextual gap that needs to be investigated further.

\section{Firm Performance}

Daft (2000) defined performance as the ability of the organization to achieve its goals and objectives. Firm performance has been the debate of practitioners and academicians for years, but it is also the ultimate dependent variable of interest for scholars of management who seek to identify variables that produce variation in performance. It is the primary differentiator of strategic management studies from other management related research. Firm performance is conceptualized and measured differently by different authors and draws different expectations from employees, shareholders, investors and the general public (Kaplan \& Norton, 2005).

Past research has used many variables to measure organizational performance and included profitability, gross profit, return on assets (ROA), return on investment (ROI), return on equity (ROE), revenue growth, stock price, liquidity and operational efficiency. Doyle (1994) argued that profitability was the most used measure of performance by most business organizations while Schendel (1991) supported use of ROA, ROE, earnings per share (EPS) and profit margin as the most common measures. Hoskisson, Johnson \& Mossel. (1994) opine that financial measures are inadequate for decision making and need to be supported by other measures such as customer satisfaction and operational efficiency.

\section{Firms Listed in the Nairobi Securities Exchange}

The Nairobi Securities Exchange (NSE) is a Kenyan based company set up by the London Stock exchange in 1920 and was registered locally in 1954 under the Societies Act (NSE, 2016). Its mandate is to promote, develop, support and discharge all the functions of a securities market. Stock exchanges have multiple roles in a country, including, raising capital for businesses and governments, mobilizing savings and creating investment opportunities as well as serving as a barometer of the economy. NSE listed companies must meet specific requirements and disclose information in a timely, complete and accurate manner to the exchange and the public. Major challenges of exchanges include cross border trading and investors becoming much more demanding (Nyasha \& Odhiambo, 2014).

Companies generally tend to improve their management standards and efficiency in order to satisfy the demands of their diverse shareholders and the more stringent rules for public corporations imposed by public stock exchanges and the government thereby improving the quality of corporate governance. Ownership by the public is important for NSE as a show of good governance and transparency. The NSE is the second stock exchange in Africa after Johannesburg to self-list. Studying companies listed in the NSE including NSE itself is considered interesting due to the following reasons first, in 2013 the NSE was the leading stock exchange in Africa and $4^{\text {th }}$ in the world, second, in 2015 NSE joined the United Nations Sustainable Stock Exchanges (SSE) initiative, third, foreign ownership of shares at the NSE total to more than a third of market value, fourth, MSCI Frontier index increased its weighting for Kenya and fifth, Capital Markets Authority has issued a revised code of governance for listed companies code of corporate governance practices for public listed companies in Kenya.

\section{Conceptual Framework}

The conceptual model Figure 1 presents a schematic picture of the researchers presumed perceptions of existing relationship among the various variables of the study. The schematic diagram captures the linkage in the literature. The model suggests relationship between corporate governance - as independent variable and firm performance as a dependent variable. 


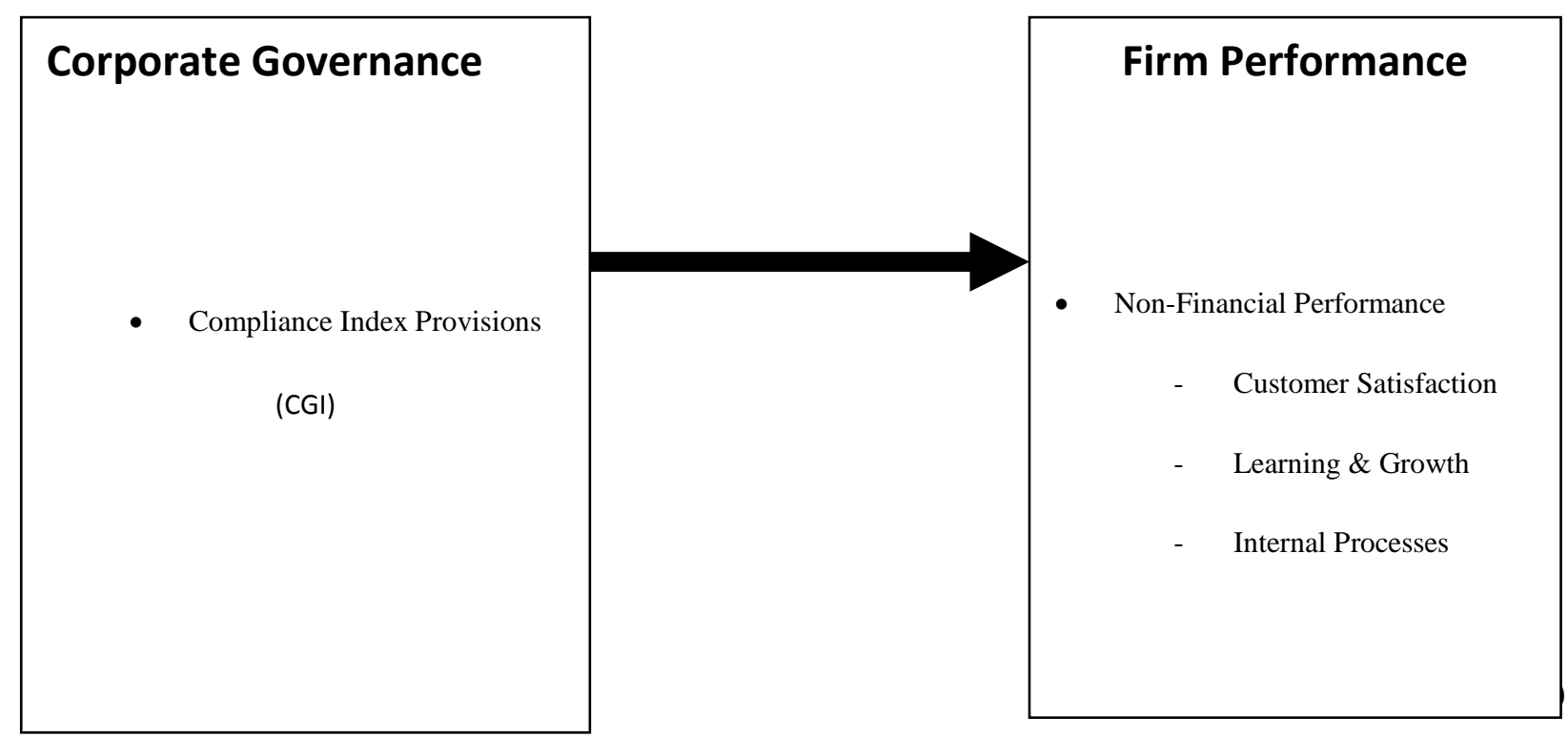

Figure 1: Conceptual Model showing the relationship between Corporate Governance and Firm Performance

As shown in figure 1 above corporate governance has influence on firm performance. Different researchers have conceptualized corporate governance and assessed the constructs differently resulting to different measurements and firm performance implications. Capital Markets Authority has issued a revised code of corporate governance practices for public listed companies in Kenya. The relationship between corporate governance constructed using the revised code and performance was under study to shed light on the aspects that are most crucial in a Kenyan context specific situation.

\section{Hypothesis}

The following hypotheses were derived from the conceptual model above.

\section{H1: There is a relationship between corporate governance and firm performance.}

The objective of the study was to establish the relationship between Corporate Governance and firm performance. A major gap presented in literature was that scholars have concentrated on the isolated effect of board, ownership structure, board diversity and financial structure on firm performance, denying other interested parties an understanding of how combined effect of corporate governance components influence non-financial performance. Although previous studies have examined the isolated effect of the components, and was not a major concern for the current study, there was need to ascertain the individual effect of each predictor variable and compare it with the combined effect. Sub-hypothesis 1a, 1b, 1c,1d, 1e, 1f and 1g comprising the corporate governance provisions as prescribed by the Capital Markets Authority tested the effect of each predictor variable on non-financial performance. The sub-hypotheses were stated as follows.

H1a: Board Operations and control has a relationship with non-financial performance H1b: Rights of shareholders has a relationship with non-financial performance. H1c: Stakeholder relations has a relationship with non-financial performance. H1d: Ethics and social responsibilities has a relationship with non-financial performance H1e: Accountability, risk management and internal audit has a relationship with non-financial performance

H1f: Transparency and disclosure has a relationship with non-financial performance H1g: Supervision and enforcement has a relationship with non-financial performance 


\section{Methodology}

The research design adopted for this study was a cross sectional descriptive survey of all firms listed on the Nairobi Securities Exchange. The descriptive design was the most appropriate for the study because it allowed the researcher to establish level of compliance of corporate by different firms, and make specific predictions on how much change was caused by predictor variable and whether the effect was significant. This was achieved through a simple linear regression analysis. Cross sectional design was preferred because the data was collected at one point in time across all 56 NSE listed firms. Each respondent either the CEO or corporation secretary filed the questionnaire once during the entire data collection period.

Instrument validation was achieved in several ways. A pre-test was done by administering the instrument to 10 conveniently selected corporation secretaries to fill. The 10 corporation secretaries were requested to evaluate the relevance, meaning and clarity. On the basis of their response, the instrument was adjusted appropriately. Content validity involved the examination of the content to determine whether it covered a representative sample of the measured items. Validity according to Kerlinger (2002) can be assessed by using expert opinion and informed judgment.

Cronbach Alpha was calculated to test reliability. The Cronbach's Alpha coefficient was used to measure the internal consistency of the measurement tool, which is commonly used in social sciences to establish the internal consistency of items or factors within and among variables of study. Nunnally (1967) argues that an Alpha coefficient of 0.7 and above is an acceptable measure. The Cronbach Alpha coefficients for corporate governance and performance in the conceptual framework were reliable registering scores of 0.835 and 0.908 respectively. This indicates that the data collected using the data collection instrument was reliable for analysis. The tests were conducted using SPSS.

Simple linear regression analysis was used to establish the nature and magnitude of the relationship. Mean scores were computed for lickert type questions. The value of coefficient of determination $\mathrm{R}^{2}$ shows the degree or amount of variation in the dependent variable attributed to the predictor variable. The Beta values show the amount of change in the dependent variable attributable to the amount of change in the predictor variable, and the $\mathrm{F}$ ratio measures the model fir, or simply put a measure of how well the equation line developed fits with observed data. The statistical significance of the hypothesized relationship was interpreted based on $\mathrm{R}^{2}, \mathrm{~F}, \mathrm{t}, \beta$ and $\mathrm{p}$ values. The simple linear regression model used is presented below.

$\mathrm{Y}=\beta_{0}+\beta_{1} \mathrm{X}_{1}+\varepsilon$

Where,

$\mathrm{Y}=$ firm performance (Dependent Variable) measured as a composite index derived from scores on customer satisfaction, internal business processes, learning and growth- skills development and learning and growth- succession planning.

$\beta 0=$ Intercept

$\beta 1=$ Beta coefficient (slope or change) in $Y$, given 1 unit change in $X_{1}$

$\mathrm{X}_{1}=$ Corporate governance (Independent Variable), measured by a composite index derived from scores on board operations and control, rights of share holders, stakeholder relations, ethics and social responsibilities, transparency and disclosure, and supervision and enforcement. .

$\varepsilon=$ Error term

\section{Results}

The objective of the study was to establish the relationship between corporate governance and performance of firm listed in the Nairobi Securities Exchange. Based on this objective data was collected using twenty four (24) items measuring corporate governance practices contained in the Capital Markets Authority revised code of corporate governance practices for public listed companies in Kenya and fourteen (14) items measuring firm performance. The items in the corporate governance scale consisted of statements that measured the extent to which organizations complied with the code in the six areas that comprised the corporate governance index. The respondents rated the extent to which itemized corporate governance practices were complied with on a scale of 1 to 5 where 1 represented "Strongly Disagree" and 5 represented 
"Strongly Agree". Similarly, items measuring performance consisted of statements that represented the extent to which the statements they applied to the firm. The rating was done on on a scale of 1 to 5 , where 1 represented, "very low" and 5 "very high". The hypothesis stated that there was a relationship between corporate governance and firm performance. The hypothesis was tested using multiple linear regression analysis first for each sub hypothesis and secondly for the overall hypothesis. The results are presented in Table 1

Table 1:Regression Results for individual influence of (BOC, RHTS, STKH, ETHSR, ACCRIS, TRDIS and on non-financial performance

\begin{tabular}{|c|c|c|c|c|c|c|c|c|}
\hline & & & ANOV & & Coeffi & ents & & Model \\
\hline & & $\mathrm{R}^{2}$ & $\mathrm{~F}$ & Sig & B & $\mathrm{t}$ & Sig & \\
\hline 1 & $\begin{array}{l}\text { Constant } \\
\text { BOC }\end{array}$ & .327 & 22.852 & .000 & $\begin{array}{l}0.542 \\
.780\end{array}$ & $\begin{array}{l}0.768 \\
4.780\end{array}$ & $\begin{array}{l}.000 \\
.000\end{array}$ & $\begin{array}{l}Y=0.542+0.80 \\
\text { BOC }\end{array}$ \\
\hline 2 & $\begin{array}{l}\text { Constant } \\
\text { RHTS }\end{array}$ & .289 & 19.079 & .000 & $\begin{array}{l}1.121 \\
.643\end{array}$ & $\begin{array}{l}1.753 \\
4.368\end{array}$ & $\begin{array}{l}.000 \\
.000\end{array}$ & $\begin{array}{l}\mathrm{Y}=1.121+0.643 \\
\text { RHTSH }\end{array}$ \\
\hline 3 & $\begin{array}{l}\text { Constant } \\
\text { STKH }\end{array}$ & .257 & 16.291 & .000 & $\begin{array}{l}2.045 \\
0.465\end{array}$ & $\begin{array}{l}4.398 \\
4.036\end{array}$ & $\begin{array}{l}.000 \\
.000\end{array}$ & $\begin{array}{l}\mathrm{Y}= \\
2.045+0.465 \\
\text { STKH }\end{array}$ \\
\hline 4 & $\begin{array}{l}\text { Constant } \\
\text { ETHSR }\end{array}$ & .303 & 20.409 & .000 & $\begin{array}{l}2.162 \\
.449\end{array}$ & $\begin{array}{l}5.525 \\
4.518\end{array}$ & $\begin{array}{l}.000 \\
.000^{\mathrm{a}}\end{array}$ & $\begin{array}{l}Y=2.162+0.449 \\
\text { ETHSR }\end{array}$ \\
\hline 5 & $\begin{array}{l}\text { Constant } \\
\text { ACCRIS }\end{array}$ & .034 & 1.631 & .105 & $\begin{array}{l}1.926 \\
.407\end{array}$ & $\begin{array}{l}1.249 \\
1.277\end{array}$ & $\begin{array}{l}.000 \\
.208\end{array}$ & $\begin{array}{l}Y=1.926+0.407 \\
\text { ACCRIS }\end{array}$ \\
\hline 6 & $\begin{array}{l}\text { Constant } \\
\text { TRDIS }\end{array}$ & .333 & 23.447 & .000 & $\begin{array}{l}0.924 \\
.705\end{array}$ & $\begin{array}{l}1.495 \\
4.842\end{array}$ & $\begin{array}{l}.000 \\
.000\end{array}$ & $\begin{array}{l}\mathrm{Y}=0.924+4.842 \\
\text { TRDIS }\end{array}$ \\
\hline 7 & $\begin{array}{l}\text { Constant } \\
\text { SUPENF }\end{array}$ & .091 & 4.723 & .023 & $\begin{array}{l}3.214 \\
.181\end{array}$ & $\begin{array}{l}9.871 \\
2173\end{array}$ & $\begin{array}{l}.000 \\
.035\end{array}$ & $\begin{array}{l}\mathrm{Y}=3.214+0.181 \\
\text { SUPENF }\end{array}$ \\
\hline
\end{tabular}

Constant: Non- Financial Performance

a Predictors : Board Operations And Control (BOC)

b Predictors: Rights of Shareholders (RHTS)

${ }^{c}$ Predictors: Stakeholder Relations (STKH)

d Predictors: Ethics and Social Responsibilities (ETHSR)

e Predictors: Accountability, Risk Management and Internal Audit (ACCRIS )

f Predictors: Transparency and Disclosure (TRDIS)

g Predictors: Supervision and Enforcement (SUPENF)

From table 1 the overall regression model in respect of board operations and control is significant $\left(\mathrm{R}^{2}=0.327, \mathrm{~F}=22.852, \mathrm{p}<0.05\right)$. These results imply goodness of fit of the model and further that operations and control used by firms listed in the Nairobi Securities Exchange explain 32.7\% of variance in their nonfinancial performance. Further, the significant Beta coefficient $(\beta=0.780, t=4.780, p<0.05)$ suggests that for every unit change (improvement in board operations and control) there is a corresponding $78 \%$ variation 
or change in non financial performance. Therefore, these results confirm the hypothesis that board operations and control has effect on non-financial performance of firms listed in the Nairobi Securities Exchange.

Likewise, from table 1 above the overall regression model in respect of rights of shareholders is significant $\left(\mathrm{R}^{2}=0.289, \mathrm{~F}=19.079, \mathrm{p}<0.05\right)$. These results imply goodness of fit of the regression model and further that rights of shareholders approach used by firms listed in the Nairobi Securities Exchange explain $28.9 \%$ of variance in their non-financial performance. Further, the significant Beta coefficient $(\beta=0.643, t=4.368$, $\mathrm{p}<0.05$ ) suggest that for every unit change in rights of shareholders there is a corresponding $64.3 \%$ variation or change in non financial performance. Therefore, these results confirm the hypothesis that rights of shareholders has effect on non-financial performance of firms listed in the Nairobi Securities Exchange.

Similarly, from table 1 above, the overall regression model in respect of stakeholder relations is significant $\left(\mathrm{R}^{2}=0.257, \mathrm{~F}=16.291, \mathrm{p}<0.05\right)$. The results suggest goodness of fit of the regression model and further that stakeholder relations approach used by firms listed in the Nairobi Securities Exchange explain $25.7 \%$ of variance in their non-financial performance. Further, the significant Beta coefficient $(\beta=0.465, t=4.038$, $\mathrm{p}<0.05)$ suggests that for every unit change in stakeholder relations there is a corresponding $46.5 \%$ variation or change in non financial performance. Therefore, these results confirm the hypothesis that rights of shareholders has effect on non-financial performance of firms listed in the Nairobi Securities Exchange.

Also from table 1 above the overall regression model in respect of ethics and social responsibility is significant $\left(\mathrm{R}^{2}=0.303, \mathrm{~F}=20.409, \mathrm{p}<0.05\right)$. These results implies goodness of fit of the model and further that operations and control used by firms listed in the Nairobi Securities Exchange explain $30.3 \%$ of variance in their non-financial performance. Further, the significant Beta coefficient $(\beta=0.449, \mathrm{t}=4.518$, $\mathrm{p}<0.05$ ) suggest that for every unit change in ethics and social responsibility there is a corresponding $44.9 \%$ variation or change in non financial performance. Therefore, these results confirm the hypothesis that ethics and social responsibilities has effect on non-financial performance of firms listed in the Nairobi Securities Exchange.

Still from table 1 above the overall regression model in respect of accountability, risk management and internal audit is not significant $\left(\mathrm{R}^{2}=0.034, \mathrm{~F}=1.631, \mathrm{p}>0.05\right)$. These results show lack of goodness of fit of the model and indicating that accountability, risk management and internal audit used by firms listed in the Nairobi Securities Exchange explain only 3.4\% of variance in their non-financial performance. Further, the significant Beta coefficient $(\beta=0.407, t=1.277, p>0.05)$ suggest that for every unit change (improvement in accountability, risk management and internal audit) there is a corresponding $40.7 \%$ variation or change in non financial performance. Therefore, these results confirm the hypothesis that accountability, risk management and internal audit has little effect on non-financial performance of firms listed in the Nairobi Securities Exchange.

Based on table 1 the overall regression model in respect of transparency and disclosure is significant $\left(\mathrm{R}^{2}=0.333, \mathrm{~F}=23.447, \mathrm{p}<0.05\right)$. These results imply goodness of fit of the model and further that transparency and disclosure used by firms listed in the Nairobi Securities Exchange explain $33.3 \%$ of variance in their non-financial performance. Further, the significant Beta coefficient $(\beta=0.705, \mathrm{t}=4.842$, $\mathrm{p}<0.05)$ imply that for every unit change in transparency and disclosure there is a corresponding $70.5 \%$ variation or change in non financial performance. Therefore, these results confirm the hypothesis that transparency and disclosure has effect on non-financial performance of firms listed in the Nairobi Securities Exchange.

Finally from table 1 above the overall regression model in respect of transparency and disclosure is significant $\left(\mathrm{R}^{2}=0.091, \mathrm{~F}=4.723, \mathrm{p}<0.05\right)$. These results imply goodness of fit of the model and further that transparency and disclosure used by firms listed in the Nairobi Securities Exchange explain $9.1 \%$ of variance in their non-financial performance. Further, the significant Beta coefficient $(\beta=0.181, t=2.173$, $\mathrm{p}<0.05)$ suggests that for every unit change in transparency and disclosure there is a corresponding $18.1 \%$ variation or change in non financial performance. Therefore, these results confirm the hypothesis that transparency and disclosure have a significant effect on non-financial performance of firms listed in the Nairobi Securities Exchange.

Based on recent streams of research the proposition that the combination corporate governance constructs has a greater influence on corporate performance than the individual effect of each construct. The simple regression analysis was performed using composite scores computed from selected measures of corporate 
governance and non-financial performance. The selected measures were board operations and control (B), rights of shareholders $(\mathrm{R})$, stakeholder relations $(\mathrm{S})$, ethics and social responsibilities $(\mathrm{E})$, transparency and disclosure (T), supervision and enforcement(S) abbreviated "BRSETS"

Accountability, risk management and internal audit provision was dropped in computing the composite governance score since it was statistically not significant. The data was used for the test of the following hypothesis:

\section{H1: There is relationship between corporate governance (BRSETS) and performance of firms listed on the Nairobi Securities Exchange.}

A simple regression analysis was performance to test the hypothesis. The results are presented in Table 2

Table 2: Regression results for the Influence of Corporate Governance (BRSETS) on Non-Financial Performance

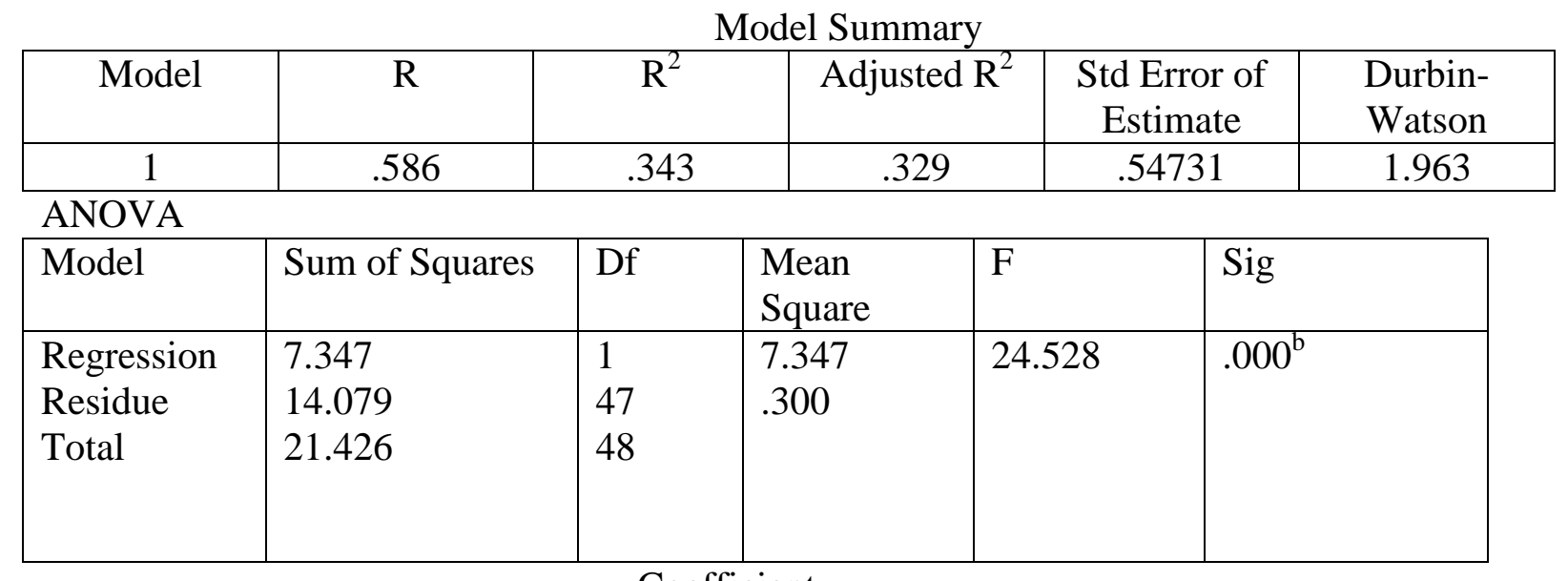

Coefficient

\begin{tabular}{|c|c|c|c|c|c|c|}
\hline \multirow[t]{2}{*}{ Model } & \multirow{2}{*}{$\begin{array}{l}\text { Unstandardized } \\
\text { Coefficient } \\
\text { B }\end{array}$} & \multirow{2}{*}{$\begin{array}{l}\text { Standardized } \\
\text { Coefficient } \\
\text { Beta }\end{array}$} & \multirow[t]{2}{*}{$\mathrm{T}$} & \multirow[t]{2}{*}{ Sig } & \multicolumn{2}{|c|}{ Collinearity Statistics } \\
\hline & & & & & Tolerance & VIF \\
\hline Constant & 1.170 & & 2.109 & .040 & & \\
\hline GC & .670 & .586 & 4.953 & .000 & 1.000 & 1.000 \\
\hline
\end{tabular}

Predictors: Corporate Governance (BRSETS)

Dependent Variable: Non-Financial Performance Measure

The regression results in Table 2 show that the relationship between corporate governance and firm performance was significant $\left(\mathrm{R}^{2}=0.343, \mathrm{~F}=24528\right.$, at $\mathrm{p}<0.05$ with $34.3 \%$ of the variation in firm performance being explained by variation in corporate governance. However, the model did not explain $65.7 \%$ of the variations in performance, implying that there were other factors associated with firm performance, which were not explained in the model. The Beta was equally significant $(\beta=.670, t=4.953$, at $\mathrm{p}<0.05)$. The Beta value implies that for one unit increase in the governance practices, firm performance increased by 0.670 or $67 . \%$. From the regression results it is evident from the hypothesis that there is a relationship between corporate governance and firm performance was supported. The results imply that board operations and control, rights of shareholders, stakeholder relations and ethics and social responsibility, transparency and disclosure and supervision and enforcement combined (accountability, risk management and internal audit was dropped because it was not statistically significant) cause an increase in non-financial performance. The results provide sufficient evidence to support the proposition that the combined effect of corporate governance on non-financial performance is greater than the individual effect of board operations and control, rights of shareholders, stakeholder relations, ethics and social responsibility, transparency and disclosure, and supervision and enforcement. This finding lends support to previous studies that found positive relationship between corporate governance and non-financial performance 
(Wilks, 2004, Brown. 2009, Kocmanova, \& Simberova, 2012 and Sandala, Manzanga and Shamhuyenhanzva 2015).

\section{Discussion}

The study tested the independent effect of board operations and control, rights of shareholders, stakeholder relations, ethics and social responsibility, accountability, risk management and internal audit, transparency and disclosure, and supervision and enforcement on firm performance. The results showed that that transparency and disclosure had the highest explanatory power $\left(\mathrm{R}^{2}=.333\right)$ of variance in non-financial performance, followed by board operations and control $\left(\mathrm{R}^{2}=.327\right)$, ethics and social responsibility $\left(\mathrm{R}^{2}=.303\right)$, rights of shareholders $\left(\mathrm{R}^{2}=.289\right)$, and stakeholder relations $\left(\mathrm{R}^{2}=.257\right)$, supervision and enforcement $(.091)$ with accountability, risk management and audit the least effect (.034) respectively. The overall models and regression coefficients were significant for the six constructs. The seventh, comprising accountability, risk management and internal audit, being statistically not significant. The study established that combined effect of the six constructs on non-financial performance was greater than the individual effect of each construct on non-financial performance.

In a previous study conducted in the East African Stock Exchanges, Okiro (2015) found that the influence of corporate governance contributed $61.1 \%$ of the change in performance. In a study of the financial institutions in Kosovo and Montenegro, Tosuni (2013) found that shareholders rights (one dimension of corporate governance) enhances performance. Studies by Gyakari (2009), Cheng et al (2011), Kalezic (2012) and Otman, 2014) also found that good corporate governance led to better performance.

This is the first study known to the researcher to investigate the relationship between corporate governance and performance using a CG index constructed from the revised 2014 Capital Markets Authority code of corporate governance practices for public listed companies in Kenya. This study therefore extends, as well, as contributes to the extant corporate governance literature by offering new evidence on compliance with, and disclosure of good corporate governance recommendations contained in the revised 2014 Capital Markets Authority code of corporate governance practices for public listed companies in Kenya.

There is now widespread recognition, as well as empirical evidence that corporate governance arrangements can substantially affect performance and many provisions have been suggested. But, which provisions among the many provisions play a key role in the link between corporate governance and performance. The Capital Markets Authority has issued a revised code of corporate governance practices for public listed companies in Kenya which has the following provisions; board operations and control, shareholder rights, stakeholder relations and ethics and social responsibilities, accountability, risk management and internal audit, transparency and disclosure and supervision and enforcement. The governance provisions that this study found that had a link with performance were board operations and control, shareholder rights, stakeholder relations and ethics and social responsibilities, transparency and disclosure with and supervision and enforcement showing a weak link. The study did not find a link on accountability, risk management and internal audit with performance.

\section{Conclusion}

Conclusively, the results supported the relationship between corporate governance and performance of firms listed in Nairobi Securities Exchange. The findings indicated that the combined effect of corporate governance constructs had a greater influence on firm performance than isolated effect of board operations and control, rights of shareholders, stakeholder relations, ethics and social responsibilities, accountability, risk management and internal audit, transparency and disclosure and supervision and enforcement.

The findings support recent streams of literature which argue that different corporate governance mechanisms may appear ineffective if investigated individually, but may have an important impact on performance in combination with other corporate governance mechanisms

\section{References}

1. Barako, D. G., \& Brown, A. M. (2008). Corporate social reporting and board representation: evidence from the Kenyan banking sector, Journal of Management and Governance, 12,(4), 309 324 
2. Berle, A.A \& Means G.C ( 1932). The Modern Corporation and Private Property. $2^{\text {nd }}$ Edition, Harcout, Brace and World, New York 1967.

3. Brown, R., \& Gorgens, T.( 2009). Corporate governance and financial performance in an Australian Context. Treasury Working Paper.

4. Cadbury Committee, (1999). Report of the Committee on the Financial aspects of Corporate Governance, Gee, London, UK.

5. Cheung, Y.L., Connelly, J.T., Jiang, P., \& Limpaphayom, P (2011). Does corporate governance predict future performance? Evidence from Hong Kong. Financial Management, Vol. 40, (1), 159197.

6. Claessens, S. (2006). Corporate governance and development. The World Bank Research Observer, $21,(1), 91-122$.

7. Cytonn Investment (2016). What is the role of corporate governance in the recent investor Losses? Cytonn Corporate Governance Report, May 2016.

8. Daft, R.L. (2000). Management $5^{\text {th }}$ Edition. The Dryden Press. Philadelphia.

9. Davis, J.H., Schoorman, F.D., Donaldson, L. (1997). Academy of Management Review: 22, 20-47.

10. Doyle, P. (1994). Setting business objectives and measuring performance. European Management Journal, Vol. 12 (2), 123-132.

11. Filatotchev, I., \& Boyd, B. K. (2009). Taking stock of corporate governance research While looking to the future. An International Review, 17, (3), 257-265.

12. Freeman, R.E. (1984). Strategic Management: A Stakeholder Approach. Pitman Publishing Inc., Massachusetts.

13. Gompers, P.A., Ishii, J.L., \& Metrick, A. (2003). Corporate governance and equity prices. Quarterly Journal of Economics 118, (1), 107-155.

14. Gyakari, N. (2009). Internal corporate governance structures and firm financial performance: Evidence from South Africa listed firms (Unpublished PhD Thesis). University of Glasgow.

15. Haniffa, R., \& Hudaib, M. (2006). Corporate governance structure and performance of Malaysian listed companies. Journal of Business Finance \& Accounting, 33, (7-8), 1034-1062.

16. Hoskisson, R.E., Johnson, R.A., \& Mossel, D.D. (1994). Corporate divestiture intensity in restructuring firms: Effects of governance, strategy and performance, Academy of Management Journal, 37, 1207-1251.

17. Irungu, G.(2016, December 11).KQ, Uchumi's Decline to zero net worth puts CMA on the Spot. The Business Daily. Retrieved February 28, 2017 from http://www.businessdailyafrica.com.

18. Jensen, M.C., \& Meckling, W.H. (1976). Managerial behavior, Agency costs and ownership structure. Journal of Financial Economics, 3, (4), 305-360.

19. Kalezić, Z (2012). Corporate governance and firm performance with special reference to the banking system: empirical evidence from Monetengro. Journal of Central Banking Theory and Practice, vol. 2, pp. 19-54.

20. Kerlinger, F.N. (2002). Foundations of Behavioural Research: Holt, Rhinehart and Winston, Inc. USA

21. Kaplan, R., \& Norton, D. (2005). The balanced score card. Measures that drive performance. Harvard Business Review, 83, (7), 172-180.

22. Kocmanova, A., \& Simberova, I. (2012). Modelling of corporate governance indicators. Engineering Economics, Vol. 23 (5) 485-495.

23. Munisi, G.H., Hermes, N., \& Randoy, T. (2009). Corporate boards and ownership structure: Evidence from Sub- Saharan Africa. International Business Review, 23, (4), 785-796.

NSE (2016). History of NSE. Retrieved June 9, 20 http://www.nse.co.ke/nse/history-of-nse- html.

24. Nunnally, J.(1967). Psychometric theory. New York. McGraw Hill.

25. Nyasha, S., \& Odhiambo, N.M. (2014). The dynamics of stock market development in Kenya. The Journal of Applied Business Research, 30 (1), 73-82.

26. Obeten, O. I., \& Ocheni, S. (2014). Empirical study of the impact of corporate governance on the performance of finance institutions in Nigeria. Journal of Good Corporate and Sustainable Development in Africa, 2, (2), 57-73. 
27. Okiro, K. (2014). Corporate governance, capital structure, regulatory compliance and performance of firms listed at the East African Community Securities Exchange. Unpublished PhD Thesis, School of Business, University of Nairobi.

28. Okoth, E. (2015, August 2). Turbulent Times for Kenya Airways as it Records 26 Billion Shillings Loss. The Daily Nation. Retrieved January 302017 from http://www.Nation.co.ke/news .

29. Otman, K (2014). Corporate governance and firm performance in listed companies in the United Arab Emirates. Unpublished PhD Thesis. College of business, Victoria University, Melbourne Australia.

30. OECD (2004). The OECD Principles of Corporate Governance. Retrieved April 30, 2016 from http://www.oecd.org/dataoecd/32/18/31557724.pdf.

31. Sandala, M., Manzanga, N., \& Shamhuyenhanzva, R. (2015). How do board characteristics influence business performance. Evidence from non-life insurance firms in Zimbabwe. Economica, Vol. 1 (4).Shabbir, A., \& Padget, C. (2005). The UK code of corporate governance: Link

32. Between compliance and performance. Working paper, ICMA Centre, University of Reading. Schendel, D., Rumelt, R.P., \& Teece, D.J. (1991). Fundamental research issues in strategy and economics. Strategic Management Journal, 12, Special issue, 5-29.

33. Solomon, J., \& Solomon, A. (2004). Corporate governance and accountability, Chichester: Wiley.

34. Tosuni, G. (2013). Impact of Corporate Governance on the Performance of Financial institutions in Kosovo and Montenegro. Unpublished PhD Thesis. Staffordshire University.

35. Wilks, J. (2004). Corporate governance and measuring performance. Measuring Business excellence Vol. 8 (4), 13-16. 